\title{
Dry period length in Montbéliarde cows and its association with selected production and functional characteristics
}

\author{
Ewa Januś and Danuta Borkowska
}

Department of Animal Breeding and Use, Faculty of Agricultural Science of Zamość, University of Life Sciences in Lublin, Zamość, Poland

\begin{abstract}
The study evaluated the effects of selected factors (dry period number, milk yield in standard lactation and length of full lactation) on the length of dry periods. The effect of dry period length on milk yield and composition, the frequency of milk samples with different somatic cell counts (SCC) and the course of lactation were also analysed. The study included 491 cycles (dry period and lactation) and 4998 results of test-day milking conducted in a herd of 230 Montbéliarde cows. The cows were kept in a free-stall barn and fed total mixed rations (TMR). The average length of the dry period was found to be 85 days. The first dry period was 34-45 days longer than subsequent ones, which may have been due to the cows becoming acclimated after having been brought to the farm as in calf heifers. Increasing milk yield in standard lactation was accompanied by significantly shorter dry periods. The most beneficial dry periods in terms of milk yield were those lasting 22-41 days. The lowest yield was noted in lactations preceded by a dry period reduced to 0-21 days. However, this milk contained the most fat, protein and dry matter and the SCC did not exceed 400000 cells $/ \mathrm{ml} \mathrm{in} 73.3 \%$ of cases. The decrease in daily milk yield from its peak in the 2 nd month to the 10th month after calving was smallest in cows with dry periods of 57-84 days, which may suggest that lactations in these cows were the most persistent.
\end{abstract}

Keywords: Montbéliarde cows; dry period; milk yield and composition; course of lactation

Abbreviations: SCC: somatic cell count, TMR: total mixed rations

Archiv Tierzucht 56 (2013) 54, 555-56

doi: $10.7482 / 0003-9438-56-053$

Corresponding author:

Ewa Januś; email: ewa.janus@up.lublin.pl

Department of Animal Breeding and Use, Faculty of Agricultural Science of Zamość, University of Life Sciences in Lublin, Szczebrzeska 102, 22-400 Zamość, Poland

(c) 2013 by the authors; licensee Leibniz Institute for Farm Animal Biology (FBN), Dummerstorf, Germany. This is an Open Access article distributed under the terms and conditions of the Creative Commons Attribution 3.0 License (http://creativecommons.org/licenses/by/3.0/).
Received: 12 August 2012

Accepted: 1 March 2013 Online: 26 April 2013 


\section{Introduction}

During the dry period, epithelial cells in the mammary gland, associated with milk yield in the following lactation, are replaced (Capuco et al. 1997, Annen et al. 2004, Church et al. 2008). This appears to be the main reason for looking for a connection between dry period length and milk yield in the subsequent lactation. Studies conducted in dairy cow populations indicate that the most beneficial length for the dry period in terms of milk yield in the following lactation is 40-60 days (Kuhn et al. 2005, Borkowska et al. 2006, Januś \& Borkowska 2010, Sawa et al. 2012a, 2012b) or 60-90 days (Węglarzy 2009). Kuczaj et al. (2009) demonstrated that the most suitable dry period length is about 6 weeks. These studies indicated that both shortening and lengthening of the dry period were harmful as was the lack of a dry period. Sorensen \& Enevoldsen (1991) found that reducing the dry period from 10 or 7 weeks to 4 weeks led to a loss in milk yield in dual-purpose Danish cows. Gulay et al. (2005) found no evidence that shortening the dry period to 30 days reduced milk production in the following lactation. Rémond \& Bonnefoy (1997) demonstrated that the milk yield in the second and third 300-day lactation in cows milked without drying off was similar to that of cows dried off for 7 weeks before calving.

In recent years, there has been increasing interest in Montbéliarde cattle in Poland, a dualpurpose breed from France. Its coloration is red and white, with a characteristic white head and white stripe on the side and rump. According to the French standard, the cattle should be of high calibre with a body weight reaching $650-800 \mathrm{~kg}$ for cows and $1000-1200 \mathrm{~kg}$ for bulls (Trela 2003). The popularity of this breed is due to such traits as high milk production, high content of protein and fat, good fertility, longevity ( $24 \%$ of cows live for 5 lactations) and easy calving (Trela 2003, Walsh et al. 2008, Koç 2011). The composition of the milk (high frequency of kappa-casein variant B) makes it suitable for the production of high-quality cheeses (Agabriel et al. 2001, Martin et al. 2009). Cattle of this breed are also distinguished by their meat performance (Chládek et al. 2005, Gołębiewski \& Brzozowski 2011). Slaughter performance ranges from 52 to $60 \%$ and the carcasses have a low fat and bone content. The breed is considered to be very healthy and resistant to changes in climate. A study by Walsh et al. (2007) found a lower SCS of Montbéliarde breed compared to Holstein-Friesian cows. Koç (2011) showed that Montbéliarde cows had a SCC that was 60378 cells/ml lower than that of the Holstein-Friesian cows. The environmental requirements of Montbéliarde cattle are considerably lower than those of other breeds, including Holstein-Friesians. Moreover, the animals are calm, trusting, have a gentle temperament and rarely exhibit nervous behaviour (Trela 2003).

The first heifers of this race arrived in Poland in 1995 and herd books for Montbéliarde cattle were opened in 2001. The average effective population size of cows of this breed was 1888 in 2011 with an average milk yield of $7093 \mathrm{~kg}$ containing $3.97 \%$ fat and $3.43 \%$ protein (PFCB\&DF 2012). Studies have shown that Montbéliarde cows in Poland have high production capacity, while their milk has a good chemical composition and high cytological quality (Borkowska \& Januś 2010, Januś \& Borkowska 2011, Kuczyńska et al. 2012). A study by Gołębiewski \& Brzozowski (2009) showed that Montbéliarde heifers attained reproductive maturity considerably later than Polish Holstein-Friesian heifers. The average first calving age was 912 in Montbéliarde heifers compared to 837 days in Polish Holstein-Friesian 
heifers. Moreover, the authors found that reproduction parameters (services per conception, service period, length of the interval between services, calving-to-first-service interval and calving-to-conception interval) in Montbéliarde cows were comparable to those of Polish Holstein-Friesians. Due to their calmer temperament, however, it can be more difficult to detect oestrus in this breed. The undeniable assets of the Montbéliarde breed have made it increasingly popular. Due to the increasing population of Montbéliarde cattle in Poland, it seems essential to conduct research on various aspects of their performance.

The aim of the study was to analyse the effect of selected factors on the length of the dry period in Montbéliarde cows. The association of dry period length with milk yield and composition after the next calving, somatic cell content in the milk and the course of lactation were also evaluated.

\section{Material and methods}

The results of a use value assessment conducted in a herd of Montbéliarde cows were used for the study. The herd, which belonged to MONTAGRO sp. $z$ 0.o., was located in the village of Wierzbica in the Tomaszów Lubelski district in Poland. In 2011, the farm had about 248 cows with an average annual milk yield of $9782 \mathrm{~kg}$ (3.36\% fat and 3.49\% protein; PFCB\&DF 2012). The cows were kept in a free-stall barn on deep litter and fed total mixed rations (TMR). The analysis included 491 cycles (dry period and lactation) and 4998 results of test-day milking from the years 2006-2011. Dry period length for individual cows was calculated based on dates of dry periods and subsequent calvings taken from breeding documentation. Five groups were distinguished based on the dry period's length: 0-21, 22-41, 43-56, 57-84 and over 84 days.

Variance analysis (PROC GLM) with SAS 9.1 (SAS Institute Inc., Cary, NC, USA) was used to evaluate the effect of dry period number $(1,2,3,4)$, milk yield (kg milk) in standard lactation preceding the dry period (up to $7000,7001-8500,8501-10000,>10000$ ) and length of complete lactation (up to 305 days, 306-365, 366-455, >455 days) on dry period length. Variance analysis was also used to evaluate the effect of different dry period lengths on milk yield ( $\mathrm{kg}$ in complete lactation and per day in standard and complete lactation), milk composition and the course of lactation. Significance of differences was determined using Duncan's test. The $\chi^{2}$ test of independence was used to analyse the frequency of samples with different SCCs (up to 100 000, 101 000-400 000, $401000-1000000$ and >1 000000 cells/ $\mathrm{ml}$ ) depending on dry period length.

\section{Results and discussion}

The average length of the dry period in the cow herd analysed was 85 days (Table 1). A high degree of variability in dry period length was noted as the standard deviation averaged 64 days. Factors found to significantly affect dry period length were dry period number and milk yield in standard lactation. The first dry period was $34-45$ days longer than subsequent ones. The prolonged first dry periods may have been due to the cows becoming acclimated after having been brought to the farm as in calf heifers. The shortest average length was calculated for the dry period following the fourth calving. This, however, occurred in the case of only 18 
cows. Behmaram \& Aslaminejad (2010) showed that the longest dry periods occurred after the first calving (on average 76 days). These were 4-21 days longer than subsequent periods between lactations. However, these differences were statistically insignificant. In a study by Vaněk (2004), the average length of the rest period was in the range of 72.34 to 77.18 days. Sawa et al. (2012b) found that longer dry periods (particularly the first) significantly decreased the percentage of cows that survived the next lactation.

Table 1

Dry period length in Montbéliarde cows taking into account the effect of the factors analysed

\begin{tabular}{llccc}
\hline \multirow{2}{*}{ Factor } & \multirow{2}{*}{$\begin{array}{c}\text { Number } \\
\text { of periods }\end{array}$} & \multicolumn{2}{c}{ Dry period length (days) } \\
\cline { 5 - 5 } & & 221 & $104^{\mathrm{A}}$ & $\mathrm{Sean}$ \\
\hline Dry period number & 1 & 156 & $70^{\mathrm{B}}$ & 36 \\
& 2 & 96 & $70^{\mathrm{B}}$ & 50 \\
& 3 & 18 & $59^{\mathrm{B}}$ & 24 \\
\hline Milk yield in standard lactation, $\mathrm{kg}$ & 4 & 149 & $119^{\mathrm{A}}$ & 81 \\
& up to 7,000 & 144 & $81^{\mathrm{Ba}}$ & 60 \\
& $7,001-8,500$ & 96 & $64^{\mathrm{BCb}}$ & 37 \\
& $8,501-10,000$ & 102 & $60^{\mathrm{C}}$ & 30 \\
\hline Duration of lactation, days & $>10,000$ & 113 & 86 & 65 \\
& up to 305 & 189 & 77 & 67 \\
& $306-365$ & 106 & 93 & 68 \\
\hline Total and average & $366-455$ & 83 & 91 & 46 \\
\hline
\end{tabular}

Mean values within a factor designated with different letters differ significantly: capital letters - at $P \leq 0.01$; lower case letters - at $P \leq 0.05$

It is commonly known that selection for increased milk production is connected with unfavourable reproduction and health disorders. It also causes a decline in functional traits (Vaněk 2004, Vacek et al. 2007, Ptak et al. 2011). In the own studies, increasing milk yield in standard lactation was accompanied by a significant decrease in dry period length $(119,81$, 64 and 60 days). A significant association between milk yield in standard lactation and dry period length was observed in another study by Januś \& Borkowska (2010), conducted in a population of Black-and-White Polish Holstein-Friesian cows. However, the shortest dry period was associated with average milk yield in standard lactation.

Prolonged lactation was not accompanied by significant changes in dry period length. The shortest dry period (77 days) was observed in the case of lactations lasting from 306 to 365 days, while the longest (93 days) was noted for lactations of 366-455 days.

The data in Table 2 show that the most frequently represented ones were dry periods lasting $42-56$ days (29.3\%) and the longest dry periods (>84 days - $30.8 \%$ ). In $3.3 \%$ of cases, lactations were not preceded by a dry period or the preceding dry period was not longer than 21 days. The most beneficial dry periods in terms of milk yield, both from calving to drying off and per day of standard lactation and complete lactation, were those lasting 22-41 days. The lowest milk yield was noted in the case of dry periods of 0-21 days. The differences between these two groups (i.e. dry periods of $22-41$ and 0-21 days) were $2679 \mathrm{~kg}$ 
for milk yield per lactation and 5.8 and $4.4 \mathrm{~kg}$ in the case of milk yield per day of standard and complete lactation, respectively. In a study by de Feu et al. (2009), the lack of a dry period was associated with lower milk yield in the first twelve months after calving and a negative effect of continuous milking on milk yield in the early lactation period was noted by Andersen et al. (2005). According to Pinedo et al. (2011), dry periods that were too short (0-30 days) or prolonged compared to those lasting 53-76 days had a negative effect on milk yield both in the early lactation period and over the course of 305 days. Sawa et al. (2012a) found that the cows whose calving was not preceded by a dry period had lower lactation yield, lower daily milk yield and also gave birth to dead calves more frequently. Andersen et al. (2005) observed a significant decrease in milk yield in the case of continuous lactation but also a significant increase in milk protein content. Watters et al. (2008) noted higher daily yield both up to the 100th day and up to the 300th day of milking in cows that calved following a dry period lasting on average 55 days ( 43.6 and $39.5 \mathrm{~kg}$, respectively) than in the case of dry periods of 34 days (41.5 and $37.7 \mathrm{~kg}$ ). Rastani et al. (2005) also noted that yield was lowest in lactations following a shortened dry period.

Table 2

Duration of lactation and milk yield in Montbéliarde cows following dry periods of different lengths

\begin{tabular}{|c|c|c|c|c|c|c|c|c|c|}
\hline \multirow[t]{2}{*}{$\begin{array}{l}\text { Dry period } \\
\text { length, days }\end{array}$} & \multicolumn{2}{|c|}{ Dry periods } & \multirow{2}{*}{$\begin{array}{c}\text { Duration of } \\
\text { lactation, } \\
\text { days }\end{array}$} & \multirow{2}{*}{$\begin{array}{l}\text { Milk yield } \\
\text { during lac- } \\
\text { tation, kg }\end{array}$} & \multicolumn{2}{|c|}{$\begin{array}{c}\text { Milk yield, kg per } \\
\text { day of lactation }\end{array}$} & \multicolumn{3}{|c|}{ Content in milk, \% } \\
\hline & $\mathrm{N}$ & $\%$ & & & standard & complete & fat & protein & dry matter \\
\hline $0-21$ & 16 & 3.3 & $324^{a}$ & $9117^{\text {Aa }}$ & $29.4^{\mathrm{Aa}}$ & $28.3^{\mathrm{A}}$ & 4.24 & $3.66^{\mathrm{a}}$ & 13.41 \\
\hline $22-41$ & 55 & 11.2 & $365^{b}$ & $11796^{\mathrm{Bb}}$ & $35.2^{\mathrm{Bb}}$ & $32.7^{\mathrm{Ba}}$ & 4.08 & 3.61 & 13.18 \\
\hline $42-56$ & 144 & 29.3 & 343 & $10468^{c}$ & $32.2^{c}$ & 30.6 & 4.13 & 3.60 & 13.19 \\
\hline $57-84$ & 125 & 25.5 & 357 & $10628^{b c}$ & $31.8^{c}$ & $29.7^{\mathrm{b}}$ & 4.15 & $3.57^{\mathrm{b}}$ & 13.21 \\
\hline$>84$ & 151 & 30.8 & 352 & $10375^{c}$ & $31.4^{\mathrm{B}}$ & $29.5^{b}$ & 4.16 & 3.62 & 13.29 \\
\hline $\begin{array}{l}\text { Total and } \\
\text { average }\end{array}$ & 491 & 100.0 & 351 & 10584 & 32.1 & 30.2 & 4.14 & 3.60 & 13.23 \\
\hline
\end{tabular}

Mean values in the columns designated with different letters differ significantly: capital letters - at $P \leq 0.01$; lower case letters - at $P \leq 0.05$

Milk obtained in lactations that began after a dry period lasting 0-21 days contained significantly $(P \leq 0.05)$ more protein (by $0.09 \%)$ compared to milk obtained from cows that calved after a dry period of 57-84 days. No significant dependence was found between dry period length and the percentage of fat and dry matter in the milk but the highest percentages were noted in lactations that took place after the shortest dry periods (0-21 days). Rastani et al. (2005) noted significantly higher fat content (4.08\%) in milk obtained during the early lactation period after a 28-day dry period compared to a dry period of 56 days (3.86\%). This milk was also richer in protein (2.97 and $2.83 \%$, respectively). Watters et al. (2008) noted higher protein content in cows whose dry period was shortened to 34 days compared with an average of 55 days ( 2.83 and $2.68 \%$, respectively).

Dry period length was significantly $(P \leq 0.01)$ associated with the frequency of different SCCs in the milk (Table 3). The results showed that a total of 3568 milk samples, $71.4 \%$ of the samples analysed, contained up to 400000 somatic cells in $1 \mathrm{ml}$ of milk. The percentage of such samples was lowest (66.0\%) in the case of dry periods of $22-41$ days. In the case of 
dry periods of 42-56 days, the frequency of samples with high cytological quality (i.e. up to 400000 somatic cells in $1 \mathrm{ml}$ of milk) was $69.4 \%$. The highest percentages of such samples ( 73.5 and $73.4 \%$ ) were noted in the case of dry periods of $57-84$ days and $>84$ days. The highest percentage (21.0\%) of milk samples with SCCs from 401000 to 1 million was noted for dry periods of 0-21 days. The percentage of such samples ranged from $14.5 \%$ to $15.4 \%$ for different dry period lengths. Milk samples containing more than 1 million somatic cells per $\mathrm{ml}$ were most frequently noted (18.6\%) in lactations preceded by a dry period of 22-41 days. The percentage of such samples decreased (to 15.3, $12.0 \%$ and $11.9 \%$ ) as dry period length increased. Węglarzy (2009) noted the highest positive dependence between these parameters in the oldest cows (4th lactation or later). The association between dry period length and SCC in milk has been analysed in many studies (Rémond et al. 1997, Rastani et al. 2005, Watters et al. 2008) but the results are not unambiguous. Rémond et al. (1997) observed a tendency for SCC to increase in cows with a shorter dry period or no dry period but this increase was not associated with an increase in cases of clinical mastitis. According to these authors, milking cows continuously can reduce the number of cases of clinical mastitis by eliminating new infections associated with cessation of milking and drying off. Rastani et al. (2005) found that shortening of the dry period from 56 to 28 days was associated with reduced SSC. Watters et al. (2008) found that shorter dry periods were not associated with SSC during the first 100 days of lactation or with occurrence of mastitis within 300 days of lactation.

Table 3

Frequency of milk samples with different somatic cell counts following dry periods of different lengths

\begin{tabular}{|c|c|c|c|c|c|c|c|c|c|c|}
\hline \multirow{3}{*}{$\begin{array}{l}\text { Dry } \\
\text { period } \\
\text { length, } \\
\text { days }\end{array}$} & \multicolumn{8}{|c|}{ Number and $\%$ of milk samples with somatic cell count, $1,000 / \mathrm{ml}$} & \multicolumn{2}{|c|}{ Total } \\
\hline & \multicolumn{2}{|c|}{ up to 100} & \multicolumn{2}{|c|}{$101-400$} & \multicolumn{2}{|c|}{$401-1,000$} & \multicolumn{2}{|c|}{$>1,000$} & \multirow[b]{2}{*}{$\mathrm{N}$} & \multirow[b]{2}{*}{$\%$} \\
\hline & $\mathrm{N}$ & $\%$ & $\mathrm{~N}$ & $\%$ & $\mathrm{~N}$ & $\%$ & $\mathrm{~N}$ & $\%$ & & \\
\hline $0-21$ & 75 & 47.8 & 40 & 25.5 & 33 & 21.0 & 9 & 5.7 & 157 & 3.1 \\
\hline $22-41$ & 199 & 33.4 & 194 & 32.6 & 92 & 15.4 & 111 & 18.6 & 596 & 11.9 \\
\hline $42-56$ & 456 & 31.8 & 539 & 37.6 & 219 & 15.3 & 219 & 15.3 & 1433 & 28.7 \\
\hline $57-84$ & 415 & 31.9 & 542 & 41.6 & 189 & 14.5 & 157 & 12.0 & 1303 & 26.1 \\
\hline$>84$ & 554 & 36.7 & 554 & 36.7 & 221 & 14.7 & 180 & 11.9 & 1509 & 30.2 \\
\hline Total & 1699 & 34.0 & 1869 & 37.4 & 754 & 15.1 & 676 & 13.5 & 4998 & 100.0 \\
\hline
\end{tabular}

$\chi^{2}=62.9-$ test value significant at $P \leq 0.01$

In cows in which lactations were preceded by no dry period or by a dry period of no more than 21 days, the highest daily yield $(38.4 \mathrm{~kg})$ was noted as early as the first month of lactation (Figure 1). Peak daily milk yield in the remaining groups occurred in the second month after calving. It should be emphasized that the increase in daily yield between the first and second month was highest $(3.5 \mathrm{~kg})$ in the case of cows whose lactations were preceded by a dry period lasting 22-41 days. From months 1 to 10 of lactation the highest daily milk yield accompanied dry periods of 22-41 days, while the lowest was noted in the case of dry periods of 0-21 days. The differences between these groups (i.e. dry periods of 22-41 and $0-21$ days) were statistically significant $(P \leq 0.01)$ up to the 8th month after calving and ranged 
from $9.2 \mathrm{~kg}$ (month 2) to $6.2 \mathrm{~kg}$ (month 8). Also, up to the 8th month after calving, milk yield in lactations not preceded by a dry period or preceded by a dry period of no more than 21 days was significantly $(P \leq 0.01$ and $P \leq 0.05)$ lower than in the groups with dry periods lasting over 41 days. In month 9 of lactation the differences between groups did not exceed $4.6 \mathrm{~kg}$ and were statistically insignificant.

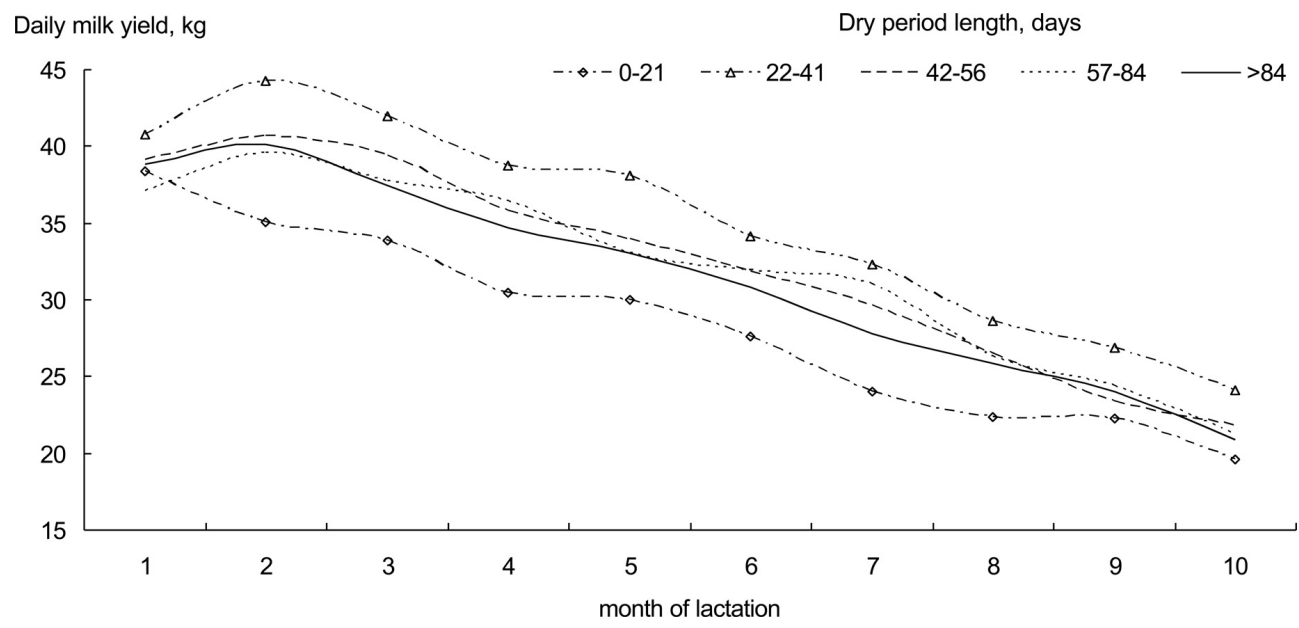

Figure 1

Daily milk yield during lactation in Montbéliarde cows following dry periods of different lengths

In the case of lactations preceded by dry periods of 22 days or longer, average milk yield per day decreased in successive months after the second month of lactation. The decrease in milk production from the peak of lactation to the 10th month after calving was greatest $(20.2 \mathrm{~kg})$ in cows that calved following a dry period of $22-41$ days. The difference in daily milk yield between the 2nd and 10th month of lactation was $19.2 \mathrm{~kg}$ in cows that calved after the longest dry periods ( $>84$ days) and $18.9 \mathrm{~kg}$ in the case of lactations following a dry period of 42-56 days. The smallest loss in production (by $18.3 \mathrm{~kg}$ ) was noted after dry periods of 57-84 days. This may indicate that lactations in these cows were the most persistent as the decrease in daily yield in successive months after its peak is one of the indicators used in evaluating lactation persistency (Guliński et al. 2004). Watters et al. (2008) demonstrated that primiparous cows whose dry period was reduced, produced more milk than multiparous cows in the last 3 weeks of lactation ( $24.1 \mathrm{vs.} 19.8 \mathrm{~kg} / \mathrm{d})$, which probably indicates greater lactation persistency. According to Grummer (2008), a suitable concentration of energy (1.56$1.69 \mathrm{MJ} \mathrm{NEL} / \mathrm{kg} \mathrm{DM}$ ) in the feeding ration before calving is essential and a slightly different intake of dry matter and energy balance in cows with dry periods of different lengths may influence the lactation curve.

To sum up, the dry period in the herd analysed lasted 85 days in average. The first dry period was 34-45 days longer than subsequent ones, which could be due to the cows becoming acclimated after having been brought to the farm as in calf heifers. Increased milk yield in standard lactation was accompanied by significantly shorter dry periods. The most beneficial dry periods in terms of milk yield both from calving to drying off and per 
day of standard and full lactation were those lasting 22-41 days. The lowest yield was noted in lactations preceded by a dry period reduced to 0-21 days. However, this milk contained the most fat, protein and dry matter and SCC did not exceed 400000 cells $/ \mathrm{ml}$ in $73.3 \%$ of cases. The decrease in daily milk yield from its peak in the 2 nd month to the 10th month after calving was smallest in cows with dry periods of 57-84 days, which may suggest that lactations in these cows were the most persistent ones. The results obtained can serve as guidelines in dairy cattle husbandry.

\section{References}

Agabriel C, Coulon JB, Journal C, De Rancourt B (2001) [Chemical composition of herd milk and farming system in the Massif central (France)]. INRA Prod Anim 14, 119-128 [in French]

Andersen JB, Madsen TG, Larsen T, Ingvartsen KL, Nielsen MO (2005) The Effects of Dry Period Versus Continuous Lactation on Metabolic Status and Performance in Periparturient Cows. J Dairy Sci 88, 35303541

Annen EL, Collier RJ, McGuire MA, Vicini JL (2004) Effect of Dry Period Length on Milk Yield and Mammary Epithelial Cells. J Dairy Sci 87 (Suppl.), E66-E76

Behmaram R, Aslaminejad AA (2010) Genetic Parameters of Productive Traits in Montbeliarde and Sarabi Cows. J Anim Vet Adv 9, 2224-2228

Borkowska D, Januś $E$ (2010) [Analysis of the influence of chosen factors on somatic cell count in milk of montbeliarde cows]. Acta Sci Pol Zootech 9, 39-45 [in Polish]

Borkowska D, Januś E, Malinowska K (2006) [Relationship between dry period length of cows and their productivity in subsequent lactation]. Sci Ann Polish Soc Anim Prod 2, 27-32 [in Polish]

Capuco AV, Akers RM, Smith JJ (1997) Mammary Growth in Holstein Cows During the Dry Period: Quantification of Nucleic Acids and Histology. J Dairy Sci 80, 477-487

Chládek G, Žižlavský J, Šubrt J (2005) A comparison of carcass proportions in Czech Pied and Montbeliarde bulls with a high carcass weight. Czech J Anim Sci 50, 109-115

Church GT, Fox LK, Gaskins CT, Hancock DD, Gay JM (2008) The Effect of a Shortened Dry Period on Intramammary Infections During the Subsequent Lactation. J Dairy Sci 91, 4219-4225

de Feu MA, Evans ACO, Lonergan P, Butler ST (2009) The effect of dry period duration and dietary energy density on milk production, bioenergetic status, and postpartum ovarian function in Holstein-Friesian dairy cows. J Dairy Sci 92, 6011-6022

Gołębiewski M, Brzozowski P (2009) [Comparison of selected reproduction parameters of Montbeliarde and Polish Holstein Friesian Black and White cows]. Med Weter 65, 566-570 [in Polish]

Gołębiewski M, Brzozowski P (2011) Comparison of meat performance of fattening bulls and culled cows of Montbeliarde and Polish Holstein-Friesian breeds and their influence on income value from their sale. Acta Sci Pol Zootech 10, 31-38

Grummer RR (2008) Nutritional and management strategies for the prevention of fatty liver in dairy cattle. Vet J 176, 10-20

Gulay MS, Hayen MJ, Head HH, Wilcox CJ, Bachman KC (2005) Milk Production from Holstein Half Udders After Concurrent Thirty- and Seventy-Day Dry Periods. J Dairy Sci 88, 3953-3962

Guliński P, Młynek K, Dobrogowska E (2004) [The importance of extended lactation for Black-and-White cows milk yield]. Zesz Nauk Przegl Hod 72, 67-75 [in Polish]

Januś $E$, Borkowska $D$ (2010) [Analysis of the influence of selected factors on dry period length of cows and the relationship with milk performance traits]. Sci Ann Polish Soc Anim Prod 6, 127-135 [in Polish]

Januś $E$, Borkowska D (2011) [Effect of selected factors on milk energy value of cow's milk from PHF BW and Montbeliarde breeds]. Food Sci Technol Qual 18, 141-149 [in Polish] 
Koç A (2011) A study of the reproductive performance, milk yield, milk constituents, and somatic cell count of Holstein-Friesian and Montbeliarde cows. Turk J Vet Anim Sci 35, 295-302

Kuczaj M, Preś J, Szulc T, Twardoń J, Kinal S, Kuryszko J (2009) [An alternative drying off of high yielding cows]. Zesz Nauk UP Wrocław 575, 157-173 [in Polish]

Kuczyńska B, Puppel K, Gołębiewski M, Kordyasz M, Grodzki H, Brzozowski P (2012) Comparison of fat and protein fractions of milk constituents in Montbeliarde and Polish Holstein-Friesian cows from one farm in Poland. Acta Vet Brno 81, 139-144

Kuhn MT, Hutchison JL, Norman HD (2005) Minimum days dry to maximize milk yield in subsequent lactation. Anim Res 54, 351-367

Martin B, Pomiès D, Pradel P, Verdier-Metz I, Rémond B (2009) Yield and sensory properties of cheese made with milk from Holstein or Montbéliarde cows milked twice or once daily. J Dairy Sci 92, 4730-4737

Pinedo P, Risco C, Melendez P (2011) A retrospective study on the association between different lengths of the dry period and subclinical mastitis, milk yield, reproductive performance, and culling in Chilean dairy cows. J Dairy Sci 94, 106-115

Polish Federation of Cattle Breeders and Dairy Farmers (PFCB\&DF) (2012) [The results of milk recording in Poland in 2011]. http://www.pfhb.pl/?strona=ocena_wyniki_2011.htm [in Polish]

Ptak E, Jagusiak W, Żarnecki A, Otwinowska-Mindur A (2011) Heritabilities and genetic correlations of lactational and daily somatic cell score with conformation traits in Polish Holstein cattle. Czech J Anim Sci $56,205-212$

Rastani RR, Grummer RR, Bertics SJ, Gümen A, Wiltbank MC, Mashek DG, Schwab MC (2005) Reducing Dry Period Length to Simplify Feeding Transition Cows: Milk Production, Energy balance, and Metabolic Profiles. J Dairy Sci 88, 1004-1014

Rémond B, Bonnefoy JC (1997) Performance of a herd of Holstein cows managed without the dry period. Ann Zoot 46, 3-12

Rémond B, Kérouanton J, Brocard V (1997) [The effect of reducing or omitting the dry period on the performance of dairy cows]. INRA Prod Anim 10(4), 301-315 [in French]

Sawa A, Bogucki M, Neja W (2012a) Dry period length and performance of cows in the subsequent production cycle. Arch Tierz 55, 140-147

Sawa A, Bogucki M, Neja W (2012b) Effect of dry period length of first-calf heifers and older cows on their performance in the next production cycle. J Centr Europ Agric 14, 341-349

Sørensen JT, Enevoldsen C (1991) Effect of Dry Period Length on Milk Production in Subsequent Lactation. J Dairy Sci 74, 1277-1283

Trela J (2003) [Acclimatization and some performance indicators in Montbeliarde cattle in Poland]. Zesz Nauk Przegl Hod 67, 67-77 [in Polish]

Vacek M, Stádník L, Štípková M (2007) Relationships between the incidence of health disorders and the reproduction traits of Holstein cows in the Czech Republic. Czech J Anim Sci 52, 227-235

Vaněk D (2004) A relationship between production and reproduction traits in cows of Czech Pied cattle. Czech J Anim Sci 49, 131-136

Walsh S, Buckley F, Berry DP, Rath M, Pierce K, Byrne N, Dillon P (2007) Effect of Breed, Feeding System, and Parity on Udder Health and Milking Characteristics. J Dairy Sci 90, 5767-5779

Walsh S, Buckley F, Pierce K, Byrne N, Patton J, Dillon P (2008) Effects of Breed and Feeding System on Milk Production, Body Weight, Body Condition Score, Reproductive Performance, and Postpartum Ovarian Function. J Dairy Sci 91, 4401-4413

Watters RD, Guenther JN, Brickner AE, Rastani RR, Crump PM, Clark PW, Grummer RR (2008) Effects of Dry Period Length on Milk Production and Health of Dairy Cattle. J Dairy Sci 91, 2595-2603

Węglarzy K (2009) Lactation productivity of dairy cows as affected by the length of preceding dry period. Anim Sci Pap Rep 27, 303-310 